\title{
Comparative study on the in vivo and in vitro antilipolytic effects of etofibrate, nicotinic acid and clofibrate in the rat
}

\author{
Carlos Bocos, Emilio Herrera * \\ Facultad de Ciencias Experimentales y Técnicas, Universidad San Pablo-CEU, P.O. Box 67, 28660 Boadilla del Monte, Madrid, Spain
}

Received 22 April 1996; revised 12 August 1996; accepted 12 August 1996

\begin{abstract}
The release of both glycerol and free fatty acids (FFA) into a medium by epididymal fat pad pieces from fed rats incubated in Krebs Ringer bicarbonate-albumin buffer supplemented or not with epinephrine decreased more in the presence of etofibrate than in the presence of equimolecular doses of nicotinic acid or clofibrate. The first drug was the only one to stimulate the rate of fatty acid re-esterification when incubations were done under basal conditions. By $3 \mathrm{~h}$ after their acute oral administration all three drugs decreased plasma FFA levels, although the effect from etofibrate was largest, the drugs enhanced or decreased plasma glycerol levels depending on both the dose and the time after treatment. Plasma triglycerides also decreased at $3 \mathrm{~h}$ after oral drug administration, and this effect was similar with etofibrate and nicotinic acid but less with clofibrate. With the exception of a decrease at $7 \mathrm{~h}$ after the highest dose $(1.2$ $\mathrm{mmol} / \mathrm{kg}$ ) of either etofibrate or nicotinic acid (but not clofibrate), plasma cholesterol levels remained stable at $7 \mathrm{~h}$ after the respective treatments. Thus, the hypocholesterolemic effect of these drugs seems secondary to their hypotriglyceridemic effect, which would be a consequence of their respective antilipolytic actions, and follows an efficiency sequence of etofibrate, nicotinic acid and clofibrate.
\end{abstract}

Keywords: Nicotinic acid; Etofibrate; Clofibrate; Lipolysis; Triglyceride; Cholesterol; Hypolipidemic drug; (Rat)

\section{Introduction}

The 3-hydroxy-3-methyl glutaryl CoA reductase inhibitors are generally recognized as the most efficient drugs for the reduction of elevated total and LDLcholesterol (Adult Treatment Panel II, 1993). However, the substantial cost of these drugs and their limited effect in raising HDL-cholesterol and decreasing elevated triglyceride levels (Tikkanen et al., 1989; Gaw and Shepherd, 1991) justifies the use of other hypolipidemic drugs that remedy these limitations. Both nicotinic acid and fibric acid derivatives still occupy a key place in our lipid-regulating formulary since both of them have been proven useful in the clinical management of primary hypertriglyceridemia and primary hypercholesterolemia, although their use is commonly restricted to a second-line position for the latter condition (Probstfield and Hunninghake, 1994; Fattore and Sirtori, 1991; Gaw and Shepherd, 1991). Etofibrate (Lipo-Merz retard, Merz, Frankfurt/Main, Germany), the ethanediol-1,2 diester of the nicotinic and clofibric

\footnotetext{
* Corresponding author. Tel.: +34-1-351.05.50; Fax: + 34-1351.04 .96$.
}

acids (Fig. 1), was developed after it showed the synergistic effects of clofibrate and nicotinic acid in decreasing elevated levels of plasma lipids (Rosenhamer and Carlson, 1980; Cayen et al., 1979). Etofibrate has been shown to be a potent hypolipidemic agent in animals (Fabiani et al., 1989; Herrera et al., 1988; Bocos et al., 1993; Bocos et al., 1995) and humans (Series et al., 1988; Hendricks and Jensen, 1986). The primary mode of action of nicotinic acid is to inhibit lipolysis in adipose tissue by inhibiting of

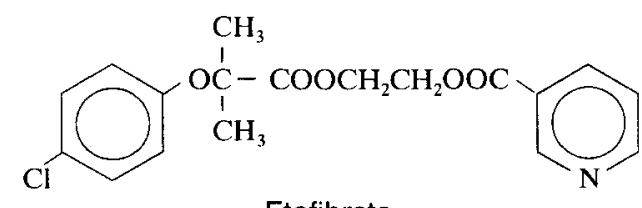

Etofibrate<smiles>CCOC(=O)C(C)(C)Oc1ccc(Cl)cc1</smiles>

Clofibrate<smiles>O=C(O)c1cccnc1</smiles>

Nicotinic acid
Fig. 1. Chemical formulas of the three compounds investigated. 
adenylate cyclase activity (Fears, 1987; Fattore and Sirtori, 1991). This prevents the utilization of free fatty acids (FFA) in the hepatic synthesis of very low density lipoproteins (VLDL) (Olsson et al., 1986), consequently reducing low-density lipoproteins (LDL) levels. The hypolipidemic effects of clofibrate, its fibric acid derivatives and etofibrate are, however, very wide-spread and while they affect several lipoprotein metabolism pathways, their primary mode of action still remains an enigma. Both clofibrate and etofibrate have also been shown to inhibit adipose tissue lipolytic activity (D'Costa et al., 1979; Bocos et al., 1993). So, the present study compares the antilipolytic effects of nicotinic acid, clofibrate and etofibrate both in vivo and in vitro and relates these to their respective effects on plasma triglycerides and cholesterol in normolipidemic rats.

\section{Materials and methods}

\subsection{In vitro experiments}

Male Sprague-Dawley rats weighing $180-220 \mathrm{~g}$ fed ad libitum purina chow diet (Panlab, Barcelona, Spain) and subjected to a $12 \mathrm{~h}$ on-off light cycle (7.00 to $19.00 \mathrm{~h}$ ) were decapitated and their epididymal fat pads pieces used to determine lipolytic activity following the method already described by us (Domínguez and Herrera, 1976), with a few modifications. After weighing, fresh epididymal fat pads were cut into small pieces and 18-20 mg were placed in vials containing $2 \mathrm{ml}$ of Krebs Ringer bicarbonate buffer ( $\mathrm{pH}$ 7.4) supplemented with $20 \mathrm{mg} / \mathrm{ml}$ of fatty acid-free bovine albumin. Half of the vials were also supplemented with $0.1 \mu \mathrm{g} / \mathrm{ml}$ of epinephrine bitartrate (Sigma Chemical Co., USA). At zero time $20 \mu \mathrm{l}$ of dimethyl sulfoxide (from Merck, Darmstadt, Germany) containing a corresponding amount of either clofibrate, nicotinic acid or etofibrate kindly supplied by Merz (Frankfurt, Germany) to give a final concentration of 0 , $10^{-5}$ or $10^{-3} \mathrm{M}$ was added to the corresponding vial. Vials were capped, gassed for 5 min with $\mathrm{O}_{2} / \mathrm{CO}_{2}$ and incubated for $120 \mathrm{~min}$ as previously described (Domínguez and Herrera, 1976) and incubation stopped by placing the vials in an ice bath. In each experiment a set of vials corresponding to each of the conditions used was placed directly in an ice bath without incubation to determine the zero time values. An aliquot of $750 \mu \mathrm{l}$ of each medium was treated with $10 \% \mathrm{HClO}_{4}$ for protein precipitation and the neutralized supernatants were used for glycerol determination (Garland and Randle, 1962). Another aliquot of each medium was used for FFA determination with a commercial kit (Wako Chemicals, Germany).

\subsection{In vivo studies}

Male Sprague-Dawley rats weighing $210-240$ g, maintained under the same conditions as above were used. At $10.00 \mathrm{~h}$ different doses $(0.2,0.5,0.8$ or $1.2 \mathrm{mmol} / \mathrm{kg}$ body weight) of either clofibrate, nicotinic acid or etofibrate freshly suspended in $2 \%$ Tween 80 or the medium (controls) were administered to the rats by stomach tube without anesthesia. At different times thereafter (3,5 and $7 \mathrm{~h}$ ) blood was collected from the tip of the tail into ice chilled heparinized receptacles. After centrifugation at $3000 \times g$ at $4^{\circ} \mathrm{C}$ for 15 min plasma was stored at $-30^{\circ} \mathrm{C}$ until processed. Aliquots of total plasma were used for FFA, triglycerides and cholesterol analysis with commercial kits (Wako Chemicals, Germany; Boehringer Mannheim, Germany, and Menarini, Italy, respectively). Other plasma aliquots were deproteinized (Somogyi, 1945) for glycerol measurement (Garland and Randle, 1962).

\subsection{Expression of the results}

Values correspond to means \pm S.E., and the statistical comparison between the groups was performed by the Student's $\mathbf{t}$ test.

\section{Results}

Adipose tissue lipolytic activity was measured in vitro using epididymal fat pad pieces from fed rats. The fat pads were incubated either under basal conditions or under lipolytic stimulating conditions created by the presence of epinephrine in the medium, which was supplemented or not with two different doses of each drug $\left(10^{-5}\right.$ and $10^{-3}$ M). As shown in Fig. 2A, nicotinic acid decreased the production of both glycerol and FFA whether tissues were incubated under basal conditions or in the presence of epinephrine, and although the effect of the $10^{-5} \mathrm{M}$ dose was not significant when considering the glycerol production of tissue pieces incubated under basal conditions, it was significant when expressed as a percentage of the respective control values $(72.1 \%, P<0.05)$. As shown in

Table 1

Free fatty acid re-esterification index (FFA/glycerol)

\begin{tabular}{|c|c|c|c|c|}
\hline \multirow[t]{2}{*}{ Treatment } & \multirow[t]{2}{*}{ Dose } & \multicolumn{3}{|c|}{ Medium of incubation } \\
\hline & & Basal & $P$ & + Epinephrine \\
\hline Controls & & $2.49 \pm 0.14$ & n.s. & $2.67 \pm 0.09$ \\
\hline Etofibrate & $\begin{array}{l}10^{-5} \mathrm{M} \\
10^{-3} \mathrm{M}\end{array}$ & $\begin{array}{l}2.11 \pm 0.31 \\
1.87 \pm 0.30\end{array}$ & $\begin{array}{l}\text { n.s. } \\
<0.01\end{array}$ & $\begin{array}{l}2.38 \pm 0.22 \\
2.91 \pm 0.08\end{array}$ \\
\hline Clofibrate & $\begin{array}{l}10^{-5} \mathrm{M} \\
10^{-3} \mathrm{M}\end{array}$ & $\begin{array}{l}2.39 \pm 0.17 \\
2.39 \pm 0.16\end{array}$ & $\begin{array}{l}\text { n.s. } \\
\text { n.s. }\end{array}$ & $\begin{array}{l}2.51 \pm 0.18 \\
2.42 \pm 0.17\end{array}$ \\
\hline Nicotinic ac. & $\begin{array}{l}10^{-5} \mathrm{M} \\
10^{-3} \mathrm{M}\end{array}$ & $\begin{array}{l}2.67 \pm 0.14 \\
2.32 \pm 0.24\end{array}$ & $\begin{array}{l}\text { n.s. } \\
\text { n.s. }\end{array}$ & $\begin{array}{l}2.90 \pm 0.10 \\
2.66 \pm 0.15\end{array}$ \\
\hline
\end{tabular}

Values are means \pm S.E. The free fatty acid re-esterification index was calculated using the (nmol FFA/100 mg tissue):(nmol glycerol/100 mg tissue) ratio. Therefore, a value near 3 means low re-esterification of free fatty acids and a value near 0 means high reesterification. The total number of vials was eight in all the cases, from four separate experiments. The asterisks correspond to the statistical comparisons versus the respective control value (incubations without the drug) $\left({ }^{*} P<0.05\right)$, whereas $P$ values correspond to the comparisons between incubation done in the presence and the absence of epinephrine. n.s., not significant. 
$\mathbf{A}$

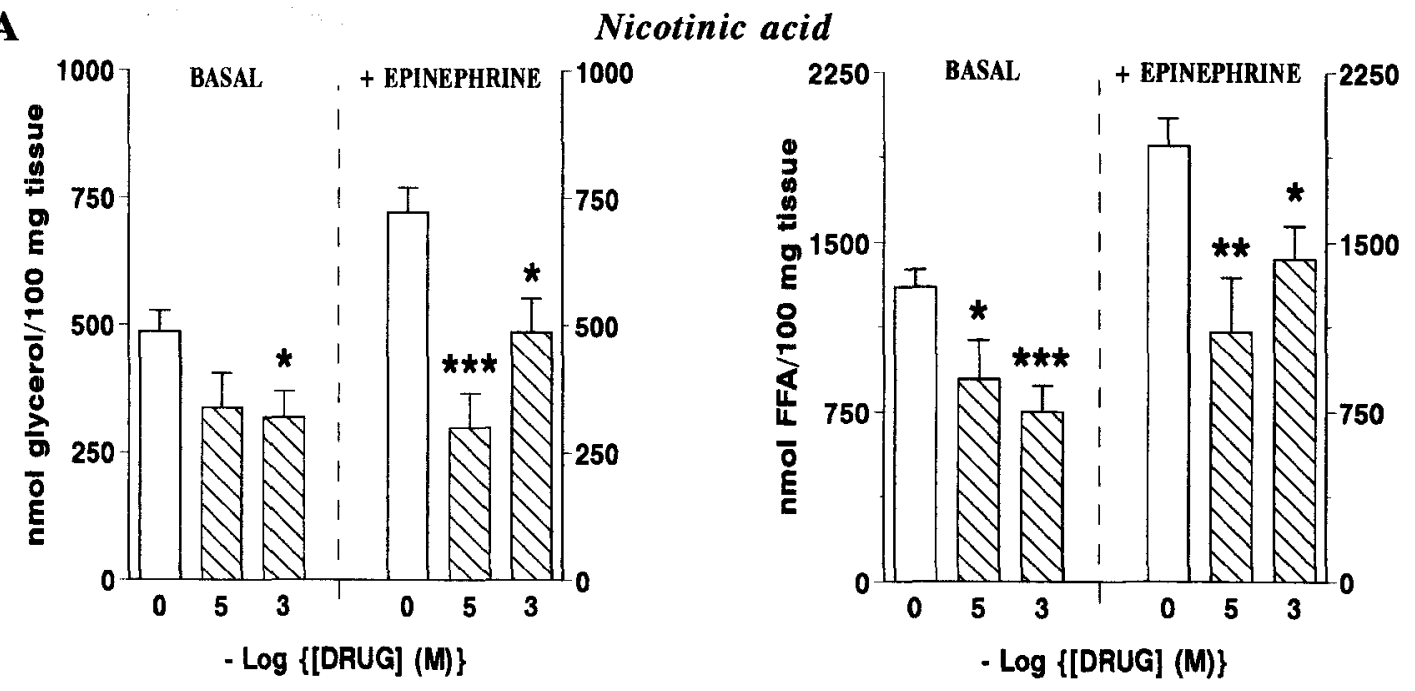

B

Clofibrate
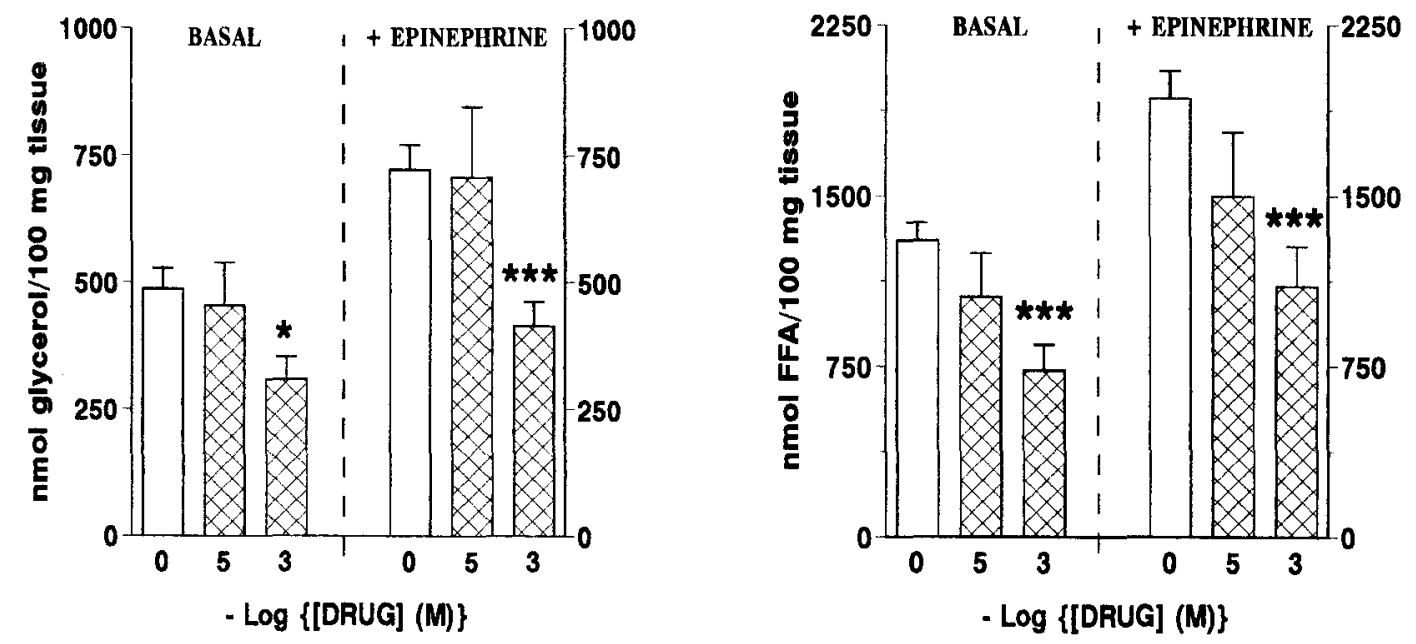

$\mathbf{C}$

Etofibrate
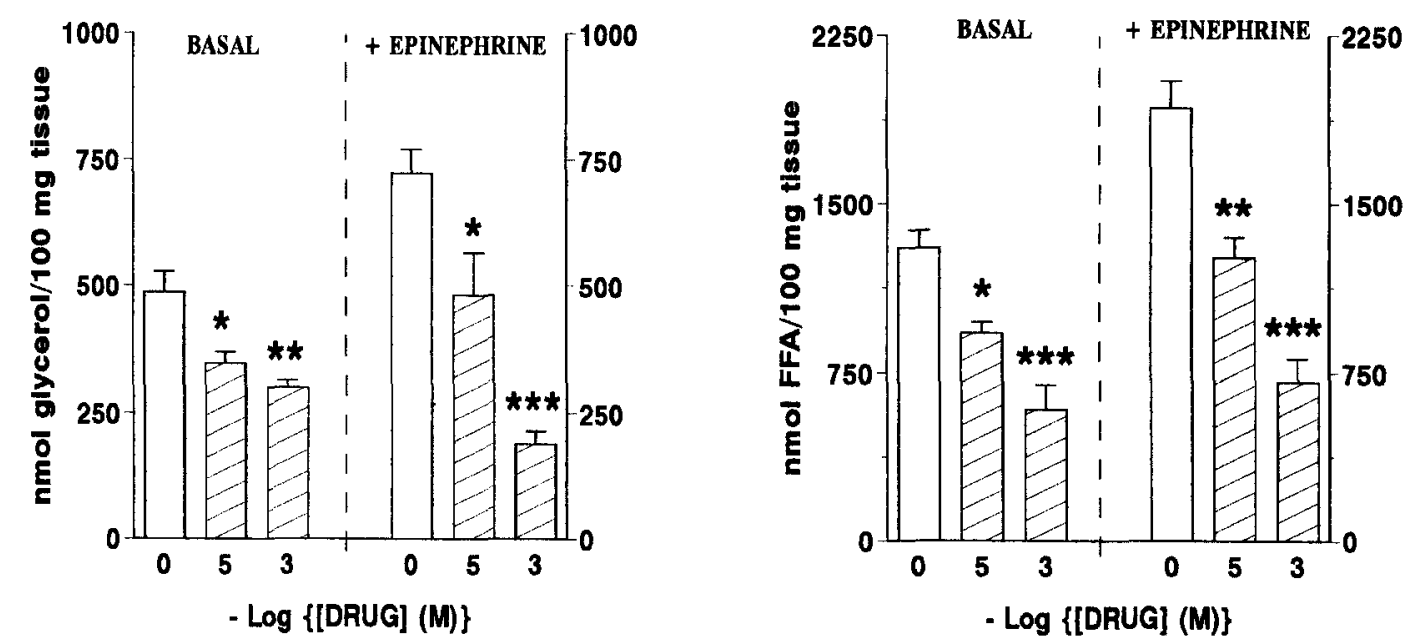

Fig. 2. Comparative in vitro antilipolytic effect of three drugs: nicotinic acid, clofibrate and etofibrate. Glycerol (left panel) and free fatty acid (right panel) release by epididymal fat pieces from untreated rats incubated in vitro for $120 \mathrm{~min}$ in the presence or absence of two different doses of the three drugs: $(A)$ nicotinic acid, $(B)$ clofibrate, $(C)$ etofibrate. Values are means $\pm S$.E. of eight vials/group from four different experiments. Asterisks correspond to the statistical comparison versus the respective control value (incubations without the drug) $(*, P<0.05 ; * *, P<0.01 ; * * *, P<0.001)$. 
Table 2

Comparative dose and time responses of plasma FFA concentration in rats to the administration of three drugs: nicotinic acid, clofibrate, and etofibrate

\begin{tabular}{|c|c|c|c|c|}
\hline \multirow[t]{2}{*}{ Dose $(\mathrm{mmol} / \mathrm{kg})$} & \multicolumn{3}{|l|}{ Time (h) } & \multirow[t]{2}{*}{ Drug } \\
\hline & 3 & 5 & 7 & \\
\hline 0.2 & $\begin{array}{l}470.46 \pm 107.48 \\
350.51 \pm 29.50^{* *} \\
132.00 \pm 21.35^{* * *}\end{array}$ & $\begin{array}{l}579.42 \pm 42.38 \\
523.68 \pm 90.48 \\
339.64 \pm 57.22\end{array}$ & $\begin{array}{l}685.90 \pm 50.23 \\
553.78 \pm 46.73 \\
518.76 \pm 104.98\end{array}$ & $\begin{array}{l}\text { Nicotinic acid } \\
\text { Clofibrate } \\
\text { Etofibrate }\end{array}$ \\
\hline 0.5 & $\begin{array}{l}177.40 \pm 5.98^{* * * *} \\
223.58 \pm 10.38^{* * *} \\
134.30 \pm 17.39^{* * *}\end{array}$ & $\begin{array}{l}551.12 \pm 124.07 \\
413.07 \pm 45.18 \\
250.42 \pm 32.77^{* *}\end{array}$ & $\begin{array}{l}801.38 \pm 143.29 \\
383.12 \pm 63.33 \\
651.10 \pm 46.02\end{array}$ & $\begin{array}{l}\text { Nicotinic acid } \\
\text { Clofibrate } \\
\text { Etofibrate }\end{array}$ \\
\hline 0.8 & $\begin{array}{l}152.08 \pm 10.70^{* * *} \\
216.88 \pm 38.86^{* * *} \\
154.00 \pm 8.81^{* * *}\end{array}$ & $\begin{array}{l}511.22 \pm 86.59 \\
336.87 \pm 54.68 \\
213.85 \pm 40.56^{* *}\end{array}$ & $\begin{array}{l}431.12 \pm 83.76 \\
482.47 \pm 63.42 \\
265.80 \pm 49.18^{* *}\end{array}$ & $\begin{array}{l}\text { Nicotinic acid } \\
\text { Clofibrate } \\
\text { Etofibrate }\end{array}$ \\
\hline 1.2 & $\begin{array}{l}294.63 \pm 47.30^{* * *} \\
241.08 \pm 21.34^{* * *} \\
151.27 \pm 17.13^{* * *}\end{array}$ & $\begin{array}{l}282.46 \pm 42.27^{* *} \\
380.98 \pm 34.32 \\
220.60 \pm 49.58^{* *}\end{array}$ & $\begin{array}{l}524.43 \pm 79.00 \\
421.65 \pm 49.44 \\
223.40 \pm 41.24\end{array}$ & $\begin{array}{l}\text { Nicotinic acid } \\
\text { Clofibrate } \\
\text { Etofibrate }\end{array}$ \\
\hline
\end{tabular}

Values are means \pm S.E. of 5-6 rats /group. Values are expressed as $\mu$ mol $/ 1$. At zero time the free fatty acids concentration was $543.95 \pm 58.23 \mu \mathrm{M}$. The asterisks correspond to the statistical comparisons versus respective control value (rats receiving placebo) $\left.{ }^{*} P<0.05 ;{ }^{* *} P<0.01 ;{ }^{*}{ }^{*} P<0.001\right)$.

Fig. $2 \mathrm{~B}$, the lowest dose of clofibrate $\left(10^{-5} \mathrm{M}\right)$ did not modify the production of either glycerol or FFA by adipose tissue pieces incubated under basal or epinephrinestimulated conditions, although both parameters did decrease when the highest dose $\left(10^{-3} \mathrm{M}\right)$ was used. As shown in Fig. 2C etofibrate decreased the production of both glycerol and of FFA in a clearly dose-dependent manner in tissues incubated in the absence or the presence of epinephrine, and this effect was always significant at either of the two doses studied.

The FFA released to an incubation medium may be taken up by the tissue for re-esterification (Grahn and Davies, 1980; Edens et al., 1990), although under normal conditions glycerol is reutilized in very small proportions (Palacín et al., 1988) due to the low glycerokinase activity present in this tissue (Robinson and Newsholme, 1967). This consideration together with the fact that over $90 \%$ of the glycerides in adipose tissue corresponds to triglycerides allows the use of the FFA/glycerol ratio in the medium as an inverse index of re-esterification (Hammond and Johnston, 1985, 1987). As shown in Table 1, applying this formula to the above results shows that neither nicotinic acid nor clofibrate affects the rate of FA esterification. However, incubation with etofibrate in the absence of epinephrine enhances esterification in a concentration dependent manner, although the difference with the control

Table 3

Comparative dose and time responses of plasma glycerol concentration in rats to the administration of three drugs: nicotinic acid, clofibrate, and etofibrate

\begin{tabular}{|c|c|c|c|c|}
\hline \multirow[t]{2}{*}{ Dose $(\mathrm{mmol} / \mathrm{kg})$} & \multicolumn{3}{|l|}{ Time (h) } & \multirow[t]{2}{*}{ Drug } \\
\hline & 3 & 5 & 7 & \\
\hline 0.2 & $\begin{array}{l}168.05 \pm 18.43 \\
189.55 \pm 10.59 * \\
137.60 \pm 8.22\end{array}$ & $\begin{array}{l}253.26 \pm 34.35 \\
255.93 \pm 29.77 \\
168.76 \pm 12.12\end{array}$ & $\begin{array}{l}221.36 \pm 36.322^{*} \\
200.15 \pm 34.66 \\
226.30 \pm 29.21^{* *}\end{array}$ & $\begin{array}{l}\text { Nicotinic acid } \\
\text { Clofibrate } \\
\text { Etofibrate }\end{array}$ \\
\hline 0.5 & $\begin{array}{l}112.62 \pm 13.25 \\
148.41 \pm 9.27 \\
114.91 \pm 5.42\end{array}$ & $\begin{array}{l}182.91 \pm 27.31 \\
198.01 \pm 14.81 \\
110.43 \pm 13.35\end{array}$ & $\begin{array}{l}299.27 \pm 19.40^{* * *} \\
137.95 \pm 22.41 \\
221.20 \pm 13.45^{* * *}\end{array}$ & $\begin{array}{l}\text { Nicotinic acid } \\
\text { Clofibrate } \\
\text { Etofibrate }\end{array}$ \\
\hline 0.8 & $\begin{array}{c}127.49 \pm 15.29 \\
160.20 \pm 21.12 \\
98.19 \pm 3.51^{*}\end{array}$ & $\begin{array}{l}273.57 \pm 23.42^{* * *} \\
220.52 \pm 27.06^{* *} \\
93.95 \pm 17.01^{*}\end{array}$ & $\begin{array}{l}230.85 \pm 32.57^{*} \\
268.17 \pm 37.69^{* *} \\
136.34 \pm 8.00\end{array}$ & $\begin{array}{l}\text { Nicotinic acid } \\
\text { Clofibrate } \\
\text { Etofibrate }\end{array}$ \\
\hline 1.2 & $\begin{array}{l}109.38 \pm 4.72 \\
126.98 \pm 14.50 \\
105.66 \pm 11.21\end{array}$ & $\begin{array}{l}90.85 \pm 7.24^{* *} \\
141.47 \pm 7.28 \\
144.45 \pm 28.81\end{array}$ & $\begin{array}{l}157.90 \pm 23.17 \\
105.80 \pm 5.83 \\
158.26 \pm 14.31\end{array}$ & $\begin{array}{l}\text { Nicotinic acid } \\
\text { Clofibrate } \\
\text { Etofibrate }\end{array}$ \\
\hline No drug & $140.99 \pm 11.26$ & $147.82 \pm 10.14$ & $150.61 \pm 6.65$ & Controls \\
\hline
\end{tabular}

Values are means \pm S.E. of 5-6 rats/group. Values are expressed as $\mu$ mol/1. At zero time the glycerol concentration was $173.93 \pm 7.55 \mu \mathrm{M}$. The asterisks correspond to the statistical comparisons versus respective control value (rats receiving placebo) $\left({ }^{*} P<0.05 ;{ }^{*}{ }^{*} P<0.01 ;{ }^{* * *} P<0.001\right)$. 
values is only statistically significant at the highest concentration $\left(10^{-3} \mathrm{M}\right)$.

In order to compare the in vivo antilipolytic responsiveness of nicotinic acid, clofibrate and etofibrate, the different equimolecular doses of the drugs were given by gavage to rats and both FFA and glycerol levels were measured in plasma at short times thereafter. As shown in Table 2, the effects of the drugs on the FFA concentration were dose and time dependent. Except for the lowest dose of nicotinic acid $(0.2 \mathrm{mmol} / \mathrm{kg})$, the different doses of all three drugs significantly reduced FFA levels at $3 \mathrm{~h}$ after their administration. At $5 \mathrm{~h}$ after administration, the four etofibrate doses and the highest dose $(1.2 \mathrm{mmol} / \mathrm{kg})$ of nicotinic acid still reduced FFA levels. At $7 \mathrm{~h}$ after gavage, only the medium-high $(0.8 \mathrm{mmol} / \mathrm{kg})$ and high $(1.2$ $\mathrm{mmol} / \mathrm{kg}$ ) doses of etofibrate were still reducing the FFA concentration in plasma (Table 2).

The acute responsiveness of plasma glycerol levels to the three drugs greatly differed from that seen for FFA. As shown in Table 3, whereas the lowest dose used $(0.2$ $\mathrm{mmol} / \mathrm{kg}$ ) of the three drugs produced significant increments in plasma glycerol levels at the 3,5 or $7 \mathrm{~h}$ times after their respective administration, higher doses produced reductions. However, although this reduction effect on glycerol levels was only found with the highest dose (1.2 $\mathrm{mmol} / \mathrm{kg}$ ) of nicotinic acid or clofibric acid (Table 3), it was already seen at the medium high $(0.8 \mathrm{mmol} / \mathrm{kg})$ dose in the rats receiving etofibrate treatment.

In order to compare these findings with the actual hypotriglyceridemic and hypocholesterolemic effects of these drugs, plasma triglycerides and cholesterol were also measured in the same animals. As shown in Table 4, plasma triglycerides decreased at $3 \mathrm{~h}$ only in the rats receiving $0.2 \mathrm{mmol} / \mathrm{kg}$ of either nicotinic acid or etofi-
Table 5

Comparative dose and time responses of plasma cholesterol concentration in rats to the administration of three drugs: nicotinic acid, clofibrate, and etofibrate

\begin{tabular}{lllll}
\hline $\begin{array}{l}\text { Dose } \\
(\mathrm{mmol} / \mathrm{kg})\end{array}$ & \multicolumn{1}{l}{ Time $(\mathrm{h})$} & \multicolumn{2}{l}{ Drug } \\
\cline { 2 - 4 } & 3 & 5 & 7 & \\
\hline 0.2 & $60.04 \pm 2.71$ & $63.55 \pm 3.27$ & $58.18 \pm 3.45$ & $\begin{array}{l}\text { Nicotinic } \\
\text { acid }\end{array}$ \\
& $61.42 \pm 2.14$ & $63.54 \pm 4.61$ & $51.88 \pm 3.21$ & $\begin{array}{l}\text { Clofibrate } \\
\text { Etofibrate }\end{array}$ \\
& $61.44 \pm 4.32$ & $61.60 \pm 4.45$ & $58.05 \pm 5.23$ & \\
0.5 & $67.85 \pm 1.01$ & $66.60 \pm 1.20$ & $64.34 \pm 2.25$ & Nicotinic \\
& & & & acid \\
& $72.80 \pm 4.23$ & $67.46 \pm 5.27$ & $60.81 \pm 5.01$ & Clofibrate \\
& $61.22 \pm 3.66$ & $53.68 \pm 5.20$ & $51.53 \pm 5.07$ & Etofibrate \\
0.8 & $57.47 \pm 2.31$ & $57.13 \pm 3.50$ & $53.69 \pm 3.54$ & Nicotinic \\
& $64.97 \pm 2.81$ & $63.90 \pm 4.20$ & $56.76 \pm 4.65$ & Ccid \\
& $61.75 \pm 4.50$ & $55.84 \pm 5.21$ & $53.99 \pm 4.28$ & Etofibrate \\
& $57.68 \pm 2.80$ & $54.59 \pm 2.24$ & $49.41 \pm 2.91 *$ & Nicotinic \\
1.2 & & & & acid \\
& $58.81 \pm 4.25$ & $57.31 \pm 2.88$ & $50.08 \pm 3.40$ & Clofibrate \\
& $59.36 \pm 2.67$ & $51.63 \pm 2.31$ & $47.32 \pm 0.94$ & Etofibrate \\
& $63.32 \pm 3.70$ & $62.78 \pm 3.33$ & $61.62 \pm 4.14$ & Controls \\
No & & & & \\
\hline drug & & & & \\
\hline
\end{tabular}

Values are means \pm S.E. of 5-6 rats/group. Values are expressed as $\mathrm{mg} / \mathrm{dl}$. At zero time the cholesterol concentration was $61.86 \pm 4.30$ $\mathrm{mg} / \mathrm{dl}$. The asterisks correspond to the statistical comparisons versus respective control value (rats receiving placebo) $\left({ }^{*} P<0.05\right)$.

brate but not clofibrate. At higher doses both nicotinic acid and etofibrate had a similar hypotriglyceridemic effect which, in the case of nicotinic acid, was still significant at the $7 \mathrm{~h}$ at the highest dose $(1.2 \mathrm{mmol} / \mathrm{kg})$ while the medium low dose $(0.5 \mathrm{mmol} / \mathrm{kg})$ of etofibrate was significant at $7 \mathrm{~h}$. Clofibrate clearly showed a smaller hy-

Table 4

Comparative dose and time responses of plasma triglyceride concentration in rats to the administration of three drugs: nicotinic acid, clofibrate, and etofibrate

\begin{tabular}{|c|c|c|c|c|}
\hline \multirow[t]{2}{*}{ Dose (mmol/kg) } & \multicolumn{3}{|l|}{ Time $(\mathrm{h})$} & \multirow[t]{2}{*}{ Drug } \\
\hline & 3 & 5 & 7 & \\
\hline 0.2 & $\begin{array}{l}26.07 \pm 6.09^{* *} \\
44.44 \pm 5.59 \\
38.81 \pm 8.90^{*}\end{array}$ & $\begin{array}{l}48.00 \pm 10.92 \\
54.92 \pm 8.77 \\
66.70 \pm 10.11\end{array}$ & $\begin{array}{l}41.37 \pm 7.59 \\
55.10 \pm 10.52 \\
82.58 \pm 11.16\end{array}$ & $\begin{array}{l}\text { Nicotinic acid } \\
\text { Clofibrate } \\
\text { Etofibrate }\end{array}$ \\
\hline 0.5 & $\begin{array}{l}14.77 \pm 1.77^{* * *} \\
35.51 \pm 5.61^{*} \\
16.64 \pm 2.14^{* * *}\end{array}$ & $\begin{array}{l}26.49 \pm 5.26 * * * \\
51.23 \pm 8.65 \\
21.94 \pm 2.30 * * *\end{array}$ & $\begin{array}{l}43.73 \pm 3.76 \\
55.72 \pm 4.74 \\
39.33 \pm 6.95\end{array}$ & $\begin{array}{l}\text { Nicotinic acid } \\
\text { Clofibrate } \\
\text { Etofibrate }\end{array}$ \\
\hline 0.8 & $\begin{array}{l}18.75 \pm 2.25^{* * *} \\
37.97 \pm 1.35^{*} \\
26.80 \pm 2.65^{* *}\end{array}$ & $\begin{array}{l}31.10 \pm 6.20^{* *} \\
45.18 \pm 5.55 \\
28.40 \pm 3.54^{* *}\end{array}$ & $\begin{array}{l}51.57 \pm 16.61 \\
71.54 \pm 7.56 \\
52.43 \pm 8.13\end{array}$ & $\begin{array}{l}\text { Nicotinic acid } \\
\text { Clofibrate } \\
\text { Etofibrate }\end{array}$ \\
\hline 1.2 & $\begin{array}{l}23.62 \pm 3.92^{* * *} \\
28.84 \pm 1.82^{* *} \\
28.14 \pm 3.89^{* *}\end{array}$ & $\begin{array}{l}21.51 \pm 1.68^{* * *} \\
48.15 \pm 3.06^{* *} \\
29.34 \pm 2.97^{* *}\end{array}$ & $\begin{array}{l}28.21 \pm 5.19^{* * *} \\
48.37 \pm 7.93 \\
41.06 \pm 5.23^{*}\end{array}$ & $\begin{array}{l}\text { Nicotinic acid } \\
\text { Clofibrate } \\
\text { Etofibrate }\end{array}$ \\
\hline No drug & $60.05 \pm 5.06$ & $63.99 \pm 5.10$ & $61.53 \pm 5.40$ & Controls \\
\hline
\end{tabular}

Values are means \pm S.E. of $5-6$ rats/group. Values are expressed as $\mathrm{mg} / \mathrm{dl}$. At zero time the trigliceride concentration was $57.99 \pm 4.85 \mathrm{mg} / \mathrm{dl}$. The asterisks correspond to the statistical comparisons versus respective control value (rats receiving placebo) $\left({ }^{*} P<0.05 ;{ }^{*}{ }^{*} P<0.01 ;{ }^{* * *} P<0.001\right)$. 
potriglyceridemic effect than either of the other two drugs, effect which was significant only at the $3 \mathrm{~h}$ time at doses of $0.5 \mathrm{mmol} / \mathrm{kg}$ and above (Table 4). As shown in Table 5 , the acute hypocholesterolemic effect of these drugs was milder than their hypotriglyceridemic one. Significant reductions of plasma cholesterol levels were only seen at 7 $\mathrm{h}$, but not before, after the highest dose of nicotinic acid or etofibrate, while clofibrate showed no significant effect at any of the doses used or at any of the times.

\section{Discussion}

Present results show the synergistic antilipolytic effect of etofibrate both in vitro and in vivo when compared to the effects from equimolecular doses of clofibrate and nicotinic acid. This is the first comparative study on the antilipolytic effect of these three drugs. Although the antilipolytic effect of both nicotinic acid and of clofibrate has been clearly established in previous reports (Stratton et al., 1985; D'Costa et al., 1979; Fuccella et al., 1980) we were unable to detect a reduction in the release of either glycerol or FFA by adipose tissue in vitro from rats that had been treated in vivo with etofibrate (Herrera et al., 1988). A dissociation between the plasma lipid-lowering effect and its inhibitory action on FFA mobilization has also been detected with nicotinic acid in humans (Carlström and Laurell, 1968), but no studies have reported on the in vitro inhibition of lipolytic activity in adipose tissue from animals that had previously received either nicotinic acid or clofibrate in vivo. This makes us suspect that, as was the case with etofibrate, the presence of either nicotinic acid or clofibrate in the incubation medium is needed to detect their respective antilipolytic effect when studying adipose tissue in vitro. This may also be the case for their respective in vivo effects, and may justify their short and dose-dependent effects in reducing the plasma FFA levels after being given acutely to rats, as was seen here.

The rate of free fatty acid re-esterification appeared clearly enhanced by etofibrate but not by either of the other two drugs. This effect is only seen when tissues were incubated under basal conditions since the rate of fatty acid re-esterification in the presence of epinephrine is practically null, agreeing with previous findings (Domínguez and Herrera, 1976; Hammond and Johnston, 1987). The effect of etofibrate enhancing the re-esterification of released FFA through lipolysis could be related to its previously reported effect of enhancing the rate of glycerol utilization for acylglycerol formation in adipose tissue from etofibrate-treated rats (Herrera et al., 1988). The ability of adipose tissue to utilize glycerol is normally very low (Palacín et al., 1988), due to its low glycerokinase activity (Robinson and Newsholme, 1967), but minor influences on this pathway may have important repercussions on the free fatty acid re-esterification capability of the tissue under conditions, like those in the present study, in which the tissue pieces are incubated in the absence of glucose and there is no other available source of glycerol3-phosphate but the glycerol released by the tissue.

The effect of these three drugs in enhancing the plasma level of glycerol when given at certain doses and times after their oral administration contrasts to their consistent effect in decreasing FFA levels. Since this latter effect reflects the antilipolytic effect of the three drugs in accordance with their respective effects in vitro, their hyperglycerolemic effects must be the consequence of a glycerol utilization rate that is even lower than the adipose tissue glycerol release rate. In the case of etofibrate we have previously reported that, when given semichronically to rats, this drug greatly decreases their ability to utilize glycerol, as indicated by the lower conversion of glycerol into both plasma lipid-soluble components (mainly acylglycerol in VLDL) and water-soluble components (mainly, glucose) (Herrera et al., 1988). Since both of these pathways, VLDL and glucose synthesis, take place specifically in the liver, and the liver is the main receptor organ for the glycerol released into circulation (Mampel et al., 1981, 1985; Carmaniu and Herrera, 1980), it is proposed that the hyperglycerolemic effect of certain doses of the three drugs observed here is more the result of an effect that decreases the overall liver consumption of glycerol than of the respective antilipolytic effect of each drug. More direct experiments are needed to test this hypothesis, although it is well known that in conditions of decreased liver ability to metabolize glycerol, such as functional hepatectomy, there is always a consistent increment in plasma glycerol levels (Mampel et al., 1981, 1985; Carmaniu and Herrera, 1980), which corresponds more to the reduced overall consumption of glycerol than to any enhanced lipolytic activity.

The comparative efficiency of the three drugs in reducing plasma FFA, with the weakest effect found for nicotinic acid and the strongest for etofibrate does not follow the same sequence as their respective in vitro effects, where clofibrate is the least efficient antilipolytic drug and etofibrate the most one. This difference may be due to the fact that whereas nicotinic acid seems to act primarily in the lipolytic cascade (D'Costa et al., 1979), both clofibrate and etofibrate act in other additional sites that can also affect the plasma level of FFA, like their enhanced liver oxidation (Herrera et al., 1988; Hawkins et al., 1987). In any case, their respective efficiency decreasing plasma triglyceride levels again follows the same sequence as that seen for their respective antilipolytic effects in vitro, the strongest effect being found with etofibrate and the lowest with clofibrate. Differences in the respective absorption rate of the three drugs, and in their effects on other parts of the triglyceride metabolism as well as the availability of FFA reaching the liver may also influence their corresponding efficiency in decreasing plasma triglyceride levels; however, our results clearly show that their respective hypocholesterolemic efficiency is much smaller than and appears later than their hypotriglyceridemic effects. It may 
then be concluded that, at least after their acute oral administration in the rat, the hypocholesterolemic effect of these three drugs is secondary to their hypotriglyceridemic one, and that this hypotriglyceridemia is mainly a consequence of their respective antilipolytic actions which, from the highest to the lowest, follows the efficiency sequence of etofibrate, nicotinic acid and clofibrate.

\section{Acknowledgements}

The authors thank Dr. G. Quack, from Merz and Co., Frankfurt/Main, Germany for providing the drugs and for his encouragement, advice and valuable help during present study. This study was supported in part by a research grant from the Commission of the European Communities (EUROLIP, of BIOMED 1). We also thank M. Morante for her technical assistance, and Carol F. Warren for her editorial help.

\section{References}

Adult Treatment Panel II, 1993, Summary of the second report of the National Cholesterol Education Program (NCEP) Expert Panel on detection, evaluation and treatment of high blood cholesterol in adults, J. Am. Med. Assoc. 269, 3015.

Bocos, C., M. Castro, G. Quack and E. Herrera, 1993, Studies with etofibrate in the rat. Part II: A comparison of the effects of prolonged and acute administration on plasma lipids, liver enzymes and adipose tissue lipolysis, Biochim. Biophys. Acta Lipids Lipid Metab. 1168, 340.

Bocos, C., E. Orozco, M. Castro, G. Quack and E. Herrera, 1995, Effect of etofibrate on bile production in the normolipidemic rat, Gen. Pharmacol. 26, 537.

Carlström, S. and S. Laurell, 1968, The effect of nicotinic acid on the diurnal variation of the free fatty acids of plasma, Acta Med. Scand. $184,121$.

Carmaniu, S. and E. Herrera, 1980, Comparative utilization in vivo of [U- $\left.{ }^{14} \mathrm{C}\right] \mathrm{glycerol},\left[2-{ }^{3} \mathrm{H}\right] \mathrm{glycerol},\left[\mathrm{U}-{ }^{14} \mathrm{C}\right.$ glucose and $\left[1-{ }^{14} \mathrm{C}\right]$ palmitate in the rat, Arch. Int. Physiol. Biochim. 88, 255.

Cayen, M.N., W.T. Robinson, J. Dubuc and D. Dvornik, 1979, Pharmacokinetics and hypolipidemic activity of clofibrate-nicotinic acid combinations in rats, Biochem. Pharmacol. 28, 1163.

D'Costa, M.A., W. Asico and A. Angel, 1979, Inhibition of rat and human adipocyte adenylate cyclase in the antilipolytic action of insulin, clofibrate, and nicotinic acid, Can. J. Biochem. 57, 1058

Domínguez, M.C. and E. Herrera, 1976, The effect of glucose, insulin and adrenaline on glycerol metabolism in vitro in rat adipose tissue, Biochem. J. 158, 183

Edens, N.K., R.L. Leibel and J. Hirsch, 1990, Mechanism of free fatty acid re-esterification in human adipocytes in vitro, J. Lipid Res. 31, 1423.

Fabiani, E., M. Crestani, B. Malavasi, M.D. Puppo, F. Farina, C. Armocida, S. Bellentani, G. Quack and E. Bosisio, 1989, The effect of etofibrate on cholesterol and bile acid metabolism in the hamster, Pharmacol. Res. 21, 567.

Fattore, P.C. and C.R. Sirtori, 1991, Nicotinic acid and derivatives, Curr. Opin. Lipidol. 2, 43.
Fears, R. 1987, Mode of action of lipid-lowering drugs, Baillieres Clin. Endocrinol. Metab. 1, 727.

Fuccella, L.M., G. Goldaniga, P. Lovisolo, E. Maggi, L. Musatti, V. Mandelli and C.R. Sirtori, 1980, Inhibition of lipolysis by nicotinic acid and by acipimox, Clin. Pharmacol. Ther. 28, 790.

Garland, P.B. and P.J. Randle, 1962, A rapid enzymatic assay for glycerol, Nature 196, 987.

Gaw, A. and J. Shepherd, 1991, Fibric acid derivatives, Curr. Opin. Lipidol. 2, 39.

Grahn, M.F. and J.I. Davies, 1980, Lipolytic agents as regulators of fatty acid esterification in rat adipose tissue [proceedings], Biochem. Soc. Trans. 8, 362.

Hammond, V.A. and D.G. Johnston, 1985, Measurement of substrate cycling in human adipocytes: a comparison of non-isotopic and isotopic techniques, Clin. Sci. 69 (suppl. 12), 15.

Hammond, V.A. and D.G. Johnston, 1987, Substrate cycling between triglyceride and fatty acid in human adipocytes, Metabolism 36, 308.

Hawkins, J.M., W.E. Jones, F.W. Bonner and G.G. Gibson, 1987, The effect of peroxisome proliferators on microsomal, peroxisomal, and mitochondrial enzyme activities in the liver and kidney, Drug Metab. Rev. 18, 441.

Hendricks, R. and K.G. Jensen, 1986, Comparison of the lipid-lowering action of bezafibrate retard and etofibrate retard in patients with type IIb hyperlipoproteinaemia, in: Pharmacological Control of Hyperlipidaemia, ed. R. Fears (J.R. Prous, Barcelona) p. 309.

Herrera, E., M.A. Lasunción, M. Castro, D. Gomez Coronado, A. Martín and G. Quack, 1988, Studies with etofibrate in the rat. Part I: Effects on glycerol, free fatty acid and triacylglycerol metabolism, Biochim. Biophys. Acta 963, 42.

Mampel, T., R. Camprodon, J. Solsona, V. Junca and E. Herrera, 1981, Changes in circulating glycerol, free fatty acids and glucose levels following liver transplant in the pig, Arch. Int. Physiol. Biochim. 89, 195.

Mampel, T., F. Villarroya and E. Herrera, 1985, Hepatectomy-nephrectomy effects in the pregnant rat and fetus, Biochem. Biophys. Res. Commun. 131, 1219.

Olsson, A.G., G. Walldius and G. Wahlberg, 1986, Nicotinic acid and its analogues. Mechanism of action, effects and clinical usage, in: Pharmacological Control of Hyperlipidaemia, ed. R. Fears (J.R. Prous, Barcelona) p. 217.

Palacín, M., M.A. Lasunción and E. Herrera, 1988, Utilization of glucose, alanine, lactate, and glycerol as lipogenic substrates by periuterine adipose tissue in situ in fed and starved rats, J. Lipid Res. 29, 26.

Probstfield, J.L. and D.B. Hunninghake, 1994, Nicotinic acid as a lipoprotein-altering agent: Therapy directed by the primary physician, Arch. Intern. Med. 154, 1557.

Robinson, J. and E.A. Newsholme, 1967, Glycerol kinase activities in rat heart and adipose tissue, Biochem. J. 104, $2 \mathrm{c}$.

Rosenhamer, G. and L.A. Carlson, 1980, Effect of combined clofibratenicotinic acid treatment in ischemic heart disease, Atherosclerosis 37, 129.

Series, J.J., M.J. Caslake, C. Kilday, A. Cruickshank, T. Demant, C.J Packard and J. Shepherd, 1988, Influence of etofibrate on low density lipoprotein metabolism, Atherosclerosis 69, 233.

Somogyi, M. 1945, Determination of blood sugar, J. Biol. Chem. 160, 69.

Stratton, G.D., D.D. Myles, P. Strong and I.F. Skidmore, 1985, The development of tolerance to antilipolytic agents by isolated rat adipocytes, Biochem. Pharmacol. 34, 275.

Tikkanen, M.J., T.S. Bocanegra, J. Findlay Walker, T. Cook and The Simvastatin Study Group, 1989, Comparison of low-dose simvastatin and gemfibrozil in the treatment of elevated plasma cholesterol, Am. J. Med. 87 (suppl.4A), 47S. 